\title{
Majuli at the Crossroads: A Study of Cultural Geomorphology
}

Dhrubajyoti Sahariah, ${ }^{+*}$ Kuleswar Singha, ${ }^{\top}$ Diganta Kr. Bora, ${ }^{\dagger}$ Sumit Kundu, ${ }^{\dagger}$ Tapashi Das, ${ }^{\dagger}$ Suchibrata Sen, ${ }^{\dagger}$ Karabi Das, ${ }^{\dagger}$ Biju Mili, ${ }^{\dagger}$ Juri Baruah, ${ }^{+}$Khagen Sarma, ${ }^{\prime}$ Mukheswar Saikia, ${ }^{\complement}$ and Anup Saikia ${ }^{\dagger}$

\begin{abstract}
Although well established elsewhere, cultural geomorphology has not yet been well-grounded in Northeast India where a perceived dearth of studies in this sub-branch of geography exists. The Brahmaputra valley, which has a long physical and cultural history, is a unique laboratory, which offers opportunities to study anthropo-geomorphologic, achaeo-geomorphologic and cultural landscapes. The Majuli river island, ostensibly the largest island in the world, houses traditional art crafts and dances, despite being continually under the siege of a plethora of physical obstacles such as flooding, bank erosion, etc. The present study aims at studying how the physical processes that constantly reshape the map of the island exert their influence on the socio-economic and cultural milieu of the region. The paper further analyses why despite all odds Majuli thrives and continues to preserve and maintain its rich natural and cultural heritage, in ways that are perhaps unparalleled in the region or even elsewhere in the globe.
\end{abstract}

Key words: cultural geomorphology, cultural landscapes, satra, Majuli river island, Assam, India

\footnotetext{
'Department of Geography, Gauhati University, Guwahati, Assam; 'Department of Forest, Government of Assam;

'Department of Geography, Jagiroad College, Assam; ' Department of Geography, Majuli College, Kamalabari, Assam

* Corresponding author, Email: dhrubajyoti@gauhati.ac.in

(C) 2013 Saharia et al. This is an Open Access article distributed under the terms of the Creative Commons Attribution License (http://creativecommons.org/licenses/by/2.0), which permits unrestricted use, distribution, and reproduction in any medium, provided the original work is properly cited.
} 


\section{Introduction}

River basins offer a unique opportunity for geographers to study both physical processes and human assemblages, and in many studies around the world, geographers have sought to establish the relationship between physical processes and the human attributes (Mcintosh, 1983). Interrelationships between landscapescale geomorphology and the development of material and nonmaterial expressions of human activity are demonstrated in many areas of the world where different cultural expressions have developed over millennial time scales (Caseldine and Turney, 2010; Fowler, 2004), and where palimpsests of human activity have been preserved differentially in the landscape (Bailey, 2007). These relationships are also well demonstrated in landscapes where there are strong physical properties and processes that have exerted their influence on the physical make-up of the landscape and the provision of its resources. This is because resource provisions, including fresh water, fertile agricultural land and route ways for trade and transport, have strongly influenced subsequent processes and spatial patterns of human development (Knight and Harrison, 2013).

Physical geography and human geography are two very deep-rooted established traditions within geography. However, in the present educational system in India, geographers are divided into two groups where physical geographers become too specialised to ignore the human components and human geographers are trained to ignore physical components or simply not competent enough or sufficiently trained to appreciate the positives that are to be had from physical geography. In the present system, geomorphology and cultural geography are two distant specialisations within geography where people study their subjects in two different dimensions. However, during the last few decades, there has been a conscious effort to undertake research in an interdisciplinary perspective considering both physical and human landscapes. For instance, cultural geomorphology and geo-archaeology share commonalities that explore the scope of understanding the cultural landscape from an interdisciplinary perspective.

Relationships between landscape-scale geomorphology and aspects of the human environment (including heritage and material cultures) are best examined in landscapes with a strong geomorphological imprint of past climatic and environmental changes, and where human activity has been present for a long period of time (Knight and Harrison, 2013).

Cultural geomorphology, on the other hand, is the discipline that studies the geomorphological component of a territory, which embodies both a cultural feature of the landscape and its interactions with cultural heritage (archaeological, historical, architectonic, etc.). The relationships between geomorphology and cultural elements can be considered schematically according to the two reciprocally integrated viewpoints:

1. Geomorphology meant as a component of a territory's cultural heritage (geomorphosistes)

2. The relationships between some cultural components (in the strict sense of the term) of a territory (archaeological, historical, architectonic assets, etc.) and the geomorphological context in which they are inserted (Panizza and Piacente, 2008).

These contributions are most relevant as archaeo-geomorphological investigations through their emphasis on cultural landscapes, encompassing geomorphology and weathering science (heritage conservation science), archaeology as well as landscape change and environmental protection, which is a part of environmental geomorphology. They treat the landscape as not only altered by human activities, which is the realm of 'anthro-geomorphology' of human impacts on the landscape, but as human culture (a cultural geomorphology that comprises more than impacts) within the physical landscape. This approach is far more appropriate for the understanding of human interpretations of landscape and adaptation to it, in addition to human interactions with (and disturbance of) the natural environment (Thornbush, 2013). Considering these perspectives, this study at- 
tempts to explore the present status of Majuli, the largest river island of the world, in terms of preservation of its natural and cultural landscape, which evolved through long interactions of river actions and people's adaptations to it.

The paper begins with a description of different physical processes that led to the development of Majuli river island. This has been followed by objective, methodology and database used in the study. After a brief discussion on geology and physical geography of the island and its impact on human activity, the paper goes on to narrate different cultural assets of the island, which has accumulated over time. Following this, it discusses the cultural heritage of Majuli shaped by both physical and human activities over the years. In the conclusion, the paper suggests that extensive conservation measures need to be adopted to save the river island from both natural disasters and cultural decay.

\section{The Study Area}

The Majuli island $\left(93^{\circ} 30^{\prime}-94^{\circ} 35^{\prime} \mathrm{E}\right.$ and $26^{\circ} 50^{\prime}$ $-27^{\circ} 10^{\prime} \mathrm{N}$ ) is located in the north of Jorhat district of Assam, India (Figure 1). The elevation varies from 60 to $85 \mathrm{~m}$ above mean sea level. The island is bounded by three major rivers: Kherkutia Suti, Subansiri and the Brahmaputra (Bhaskar et al., 2010).

Majuli was a cluster of 15 large and numerous small islands in 1792 (Sarma and Phukan, 2004) which have undergone changes in areal extension in different periods of time (Table 1 ). This largest river island is a home to the pristine cultural heritage of Assam and the Vaisnavite shrines, popularly known as Satras. As such, the island has been a principal place of pilgrimage for the last 400 years. However, presently it is well known for having suffered from two natural hazards: severe bank erosion and flooding (Sarma and Phukan, 2004).

The Brahmaputra river is characterised by high seasonal variability in flow, sediment transport and channel pattern ${ }^{1}$ (Goswami et al., 1999; Coleman, 1969). In the valley of Assam, it flows in a highly braided channel (Goswami, 1985) with the presence of numerous laterals, midchannel bars and islands. Most of them are transient in nature, being submerged during high monsoon flows and drastically change their geometry and location. The very existence of Majuli, and a home to 1, 67,245 people, based on 2011 census, is endangered because of the erratic behaviour of the river Brahmaputra.

The severity of the erosion might be understood from the fact that the area of island, including some sand chars and chaparis (the latter are local names for the numerous small and relatively recently formed river islands near the main island) has reduced in recent years. The available data indicate an erosion rate of $1.9 \mathrm{sq}$. $\mathrm{km} / \mathrm{yr}$ for the period of 1920-1998 (Kotoky et. al., 2003). The reasons as to why the Brahmaputra river has so intensely savaged the Majuli river island are not far to seek. The Brahmaputra ranks fourth among the largest rivers of the world with regard to mean annual discharge (Mirza, and Dixit, 1997). The estimated annual sediment yield of the Brahmaputra is 1028-ton sq. $\mathrm{km}$, the highest among the world's largest rivers. However, the sediment yield of the river Ganges is only 502-ton sq. km although its basin area is twice as large as the Brahmaputra (Baruah, 1994). The lateral change and meandering of the courses of the Ganges and Brahmaputra rivers in recent history have significant influence on the morphology of their alluvial floodplains (Brammer, 1996; Mirza et. al, 2001).

\section{Objectives}

The main objective of the paper is to observe as to how physical and anthropogenic forces blend together to transform Majuli from a mere river island to one of the major cultural hubs of Assam.

\footnotetext{
${ }^{1}$ The channel pattern refers to limited reaches of the river as seen in plain view that can be defined as straight, sinuous, meandering, or braided (Goswami, 1999).
} 

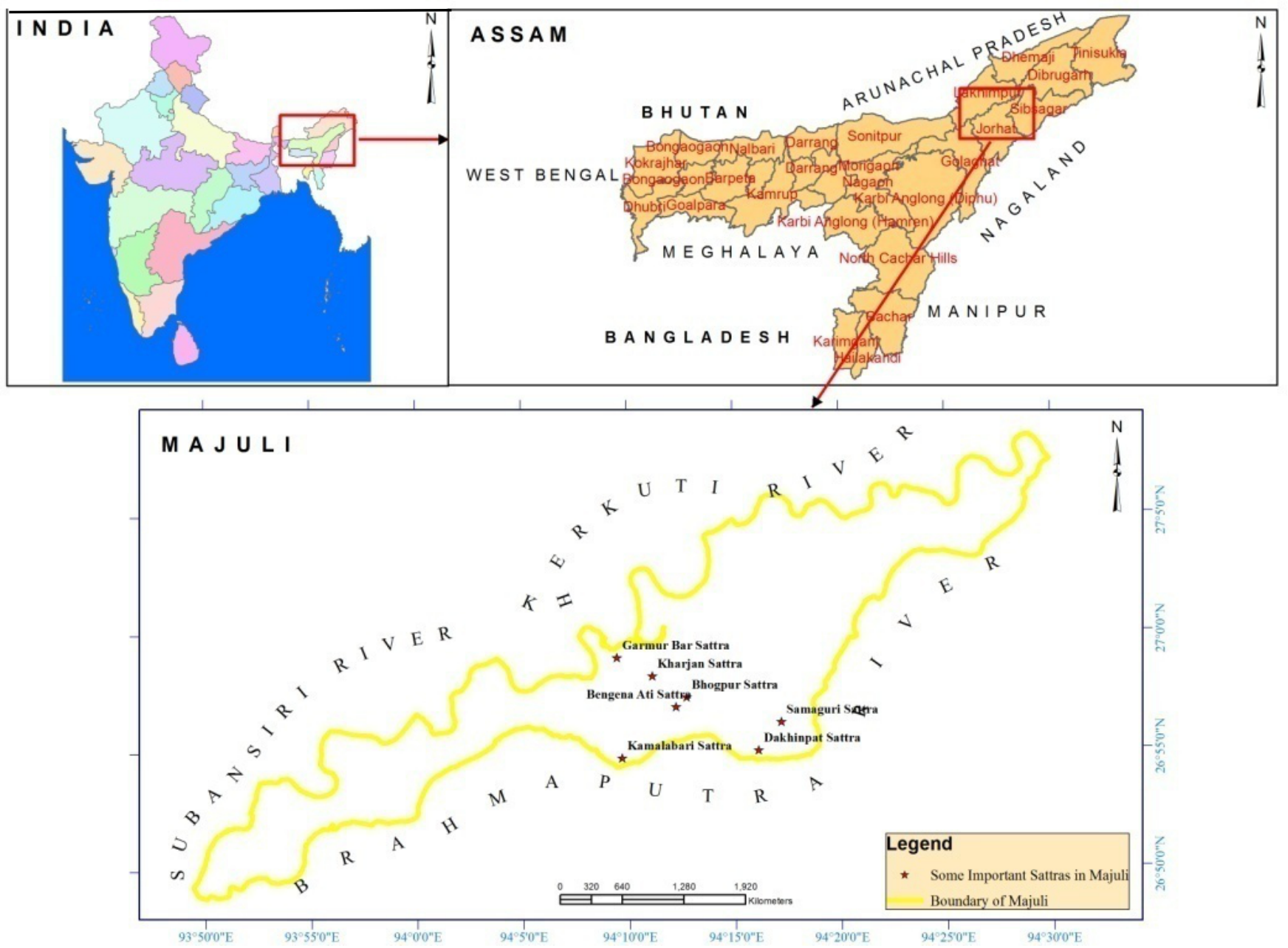

Figure 1: Location Map of Majuli

\begin{tabular}{|l|l|}
\hline \multicolumn{2}{|l|}{ Table 1: Temporal Variation of Land Area of Majuli River Island } \\
\hline Year & Area in sq. $\mathbf{~ k m}$ \\
\hline 1901 & 1255 \\
\hline 1917 & 751.31 \\
\hline $1966-1972$ & 564.01 \\
\hline 1996 & 453.76 \\
\hline 2001 & 421.65 \\
\hline Sources: Sarma and Phukan, 2004; Allen et al. 1905 \\
\hline
\end{tabular}

\section{Methodology and Database}

A more general research methodology has been adopted for this paper, which has been divided into few stages. In the first phase, a review of the literature on Majuli and the Brahmaputra valley has been done to record the major physical forces, geomorphic history and cultural history of the region. Second, the identification of geomorphological causes, which conditioned the location of a given cultural asset, is considered. Third, how the different socio-economic need of the people such as hous- ing, agriculture, water source, building material, transport, etc. are met from the given environment and how these unique assemblage of socio-economic and physical conditions give rise to a unique cultural milieu of the region are taken up for further analysis. This paper tries to give a comprehensive understanding of physical forces that helped Majuli to gain its cultural assets. 
The contributors of this paper made a field trip to Majuli on April 2013 and visited different Satra institutions, cultural centres, temporary camps of flood-affected people and areas affected by erosion of the river Brahmaputra. A lot of primary information was collected during that visit and rest of the information is collected by reviewing published materials such as journal articles, census data, books and monographs.

\section{Geology and Physical geography of Majuli and Its Implications for Human Activity}

Geologically, the island is a part of the great alluvial tract of the river Brahmaputra, which is by nature a geosynclinal basin ${ }^{1}$ formed concomitantly with the elevation of the Himalayas to its north. The island, along with the floodplains of the river Brahmaputra in its adjoining areas, is formed by alluvial deposits in the form of older alluvium, newer alluvium and recent deltaic deposits of the Pleistocene age (Krishnan, 1982). Moreover, a very complex geological setting of very young and un-weathered sedimentary formations covering the entire Brahmaputra basin surrounds the area. On the northern side, the basin is flanked by subHimalayan ranges consisting mainly of tertiary sandstone, and is marked by the presence of many raised, relatively young terraces. On the eastern and southern sides, the Brahmaputra valley borders with the Naga-Patkai ranges consisting of tertiary formations riddled with numerous active faults. Being an active floodplain, the island is marked by an array of alluvial features including natural levees, crevasses, splay deposits, point bars and channel bars. The main channel of the river Brahmaputra on the southern side is characterised by rapid aggradation, dramatic channel shifts and excessive bank line recession (Kotoky et al., 2003). The island and the valley as a whole are seismically very active. The seismic activity in the region has a great impact on the fluvio-sedimentary regime of the river Brahmaputra and its tributaries. The climate of the island and the entire Brahmaputra

\footnotetext{
${ }^{1}$ Broad elongated depression in the earth's crust containing great thicknesses of sediment (please refer to: Knopf, 1948).
}

basin lie within monsoon rainfall regime receiving annual rainfall to the tune of $2,153 \mathrm{~mm}$. The temperature varies from $28^{\circ}$ to $33^{\circ} \mathrm{C}$ and relative humidity varies from 54 per cent to 86 per cent. Given these circumstances, the Majuli river island is prone to severe erosion.

The island was a narrow and long piece of land called Majuli (land in the middle of two parallel rivers) that had Brahmaputra flowing in the north and the Burhidihing flowing in the south, until they met at Lakhu. Frequent earthquakes in the period 1661-1696 set the stage for a catastrophic flood in 1750 that continued for 15 days and is mentioned in historical texts and reflected in folklore. As a result of this flood, the Brahmaputra split into two anabranches ${ }^{2}-$ one flowing along the original channel and the other flowing along the Burhidihing channel and the Majuli island was formed. The Burhidihing's point of confluence moved $190 \mathrm{~km}$ east, the southern channel, which was the Burhidihing, became the Burhi Xuti, and the northern channel, which was previously the Brahmaputra, became the Luit Xuti. In due course of time, the flow in the Luit Xuti decreased, and it came to be known as the Kherkutia Xuti; and the Burhi Xuti expanded via erosion to become the main Brahmaputra river (Sarma and Phukan, 2004).

The landscape of Majuli is a combination of agricultural land, grassland, water bodies and sandbars (Table 2). The ecological setting in every part of the world has its own characteristic that moulds the socio-economic and cultural milieu of its inhabitants. In the said context, the socio-cultural environment of the Brahmaputra valley too gave birth to the Satra institution. The distribution pattern of the Satra institution is interesting. These are located on the bank of the river Brahmaputra and its tributaries. These institutions are situated in the plains area or low-lying areas of the Brahmaputra valley instead of highland. The Satras were established by Mahapurush Srimanta Sankardeva and his

\footnotetext{
${ }^{2} \mathrm{An}$ anabranch is a section of a river or stream that diverts from the main channel or stem of the watercourse and re-joins the main stem downstream (North et al., 2007).
} 
disciples like Madhav Deva, Damodar Deva and other preachers during 1500-1600 AD. In those days, the key means of transport and communication was only via water, so within the island, the side of the rivers established these institutions. Added to this, geographical isolation alongside idyllic environment of the island too (with no external disturbance) contributed to the establishment of the Satras. Evidently,
65 Satras were established at Majuli (Sarma, 2003). It is to be noted here that the germination of ideas and development of Satra at Majuli took place at Dhuwahat Belaguri in the year 1522. Its society, culture and even its economy are largely to be viewed in the context of its being a land of the Vaishnavite monasteries or Satra (Nath, 2009).

\begin{tabular}{|l|l|}
\hline \multicolumn{2}{|l|}{ Table 2: Land Use Categories of Majuli island in $\mathbf{2 0 1 0}$} \\
\hline Land Use Categories & Area in Hectares \\
\hline Woodlands & 3575.97 \\
\hline Grasslands & 18835.5 \\
\hline Non Forest/Agriculture land & 23674.3 \\
\hline Water & 3575.97 \\
\hline Sand bar & 4922.55 \\
\hline Total & 54584.29 \\
\hline Source: Image analysis based on landsat data \\
\hline
\end{tabular}

\section{The Culture and Heritage of Majuli}

As noted elsewhere, Majuli has been the cultural capital and the cradle of Assamese civilisation for the past 500 years. The Satra set-up helped preserve antiques such as weapons, utensils, jewellery and other items of cultural significance. Pottery is made in Majuli, mainly in the Salmora region, from beaten clay and burnt in driftwood-fired kilns in the same mode carried out by the people of the ancient Harappa civilisation and sold through ancient barter system. The handloom works of various indigenous residents of Majuli, such as Missings who weave Jim (ribbed quilts) are known worldwide. Sociologists therefore have stressed and laid emphasis on the preservation of these unique socio-cultural values, whose culture and dance forms are untouched by modernism (Sarma, 2012). It is noteworthy here that in 2004, Government of India nominated Majuli for its inclusion in the 'cultural landscape' category of the UNESCO World Heritage list. Although this appeal has been rejected in 2012 for the third time, yet it bears significance in the preservation of cultural landscape of Majuli. The rejection of Majuli's nomination is a pointer to the laxity on the part of both the central and state governments in presenting a convincing dossier pertaining to its case as a claimant to the status. ${ }^{1}$ What is ironical is that the callous culture of the Ministry of Cultural Affairs, Assam has failed to revise the incomplete dossier for reconsideration of Majuli in the coveted UNESCO World Heritage list of $2014 .^{2}$

Notwithstanding in this cultural repository, where all faiths irrespective of caste and community abides, Raas, which depicts the life of Lord Sri Krishna, is the main festival and celebrated every year in autumn. Literally, every individual gets involved to make this three-day celebration a grand success. People from different nooks and corners of the country converge to celebrate this festival, which also includes a number of expatriate members of the community. The Satras have also honed certain art and craft traditions, which can now be found only here, and exist nowhere else. In Natun Samuguri Satra for example, one can still

\footnotetext{
${ }^{1}$ Dwaipayan, (2013, September 25). World Heritage Site tag and Majuli, The Assam Tribune, (p. 6).

${ }^{2}$ Revised Majuli dossier not yet ready (2013, November 21).The Assam Tribune, available at: http://www.assamtribune.com/scripts/detailsnew.asp?i $\mathrm{d}=$ nov2113/at09 (accessed November 21, 2013).
} 
find the craft of mask making (See Fig-2); and in the Kamalabari Satra, the finest boats are made.

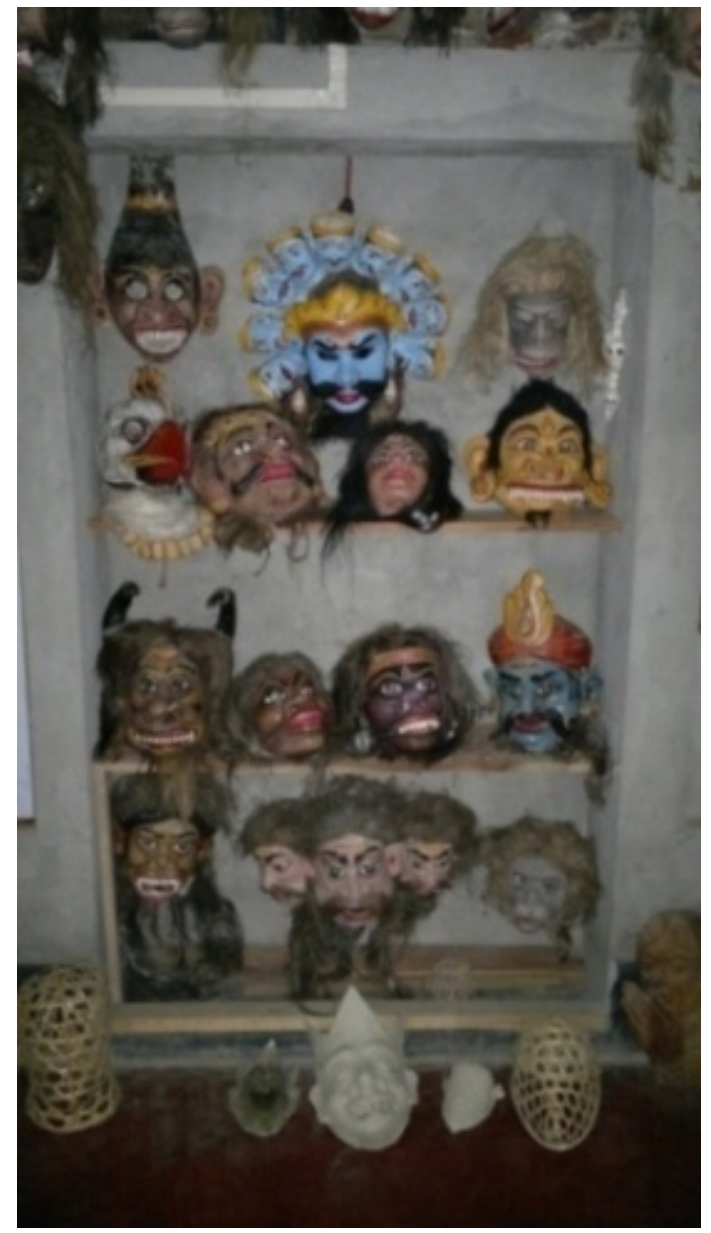

Figure 2: Masks in Samaguri Satra (Photo: D. Sahariah, 2013)

\section{Neo-Vaishnavite Satras}

The colourful hub of Assamese neo-Vaishnavite culture still survives but, as mentioned above, remains highly threatened for having suffered from two natural hazards: severe bank erosion and flooding. Historical records unfold that Mahapurush (Saint) Srimanta Sankardeva himself took refuge in Majuli and spent a couple of months at Belguri in West Majuli, which was a place of grandeur for the historic and auspicious and known for Manikanchan Sanjog, the first meeting between Mahapurush Srimanta Shankardeva and Mahapurush Madhavdeva, which was also the first Satra in Majuli. After the 'Manikanchan Sanjog', 65 Satras were set up. However, today only 22 of the original 65 still survive. The establishment of 65 Satras in Majuli is reflective of the importance of Majuli to the Satras of Assam.
The main surviving Satras are:

- Dakhinpat Satra: Founded by Banamalidev, a supporter of Raasleela, this is now observed as one of the festivals of Assam.

- Garamurh Satra: This Satra was founded by Lakshmikanta Deva. During the end of autumn, the traditional Raasleela is enacted with pomp and celebrations. Ancient weapons called 'Bartop' or cannons are preserved here.

- Auniati Satra: Founded by NiranjanPathak Deva, the satra is famous for the Paalnaam $^{1}$ and Apsara dances and also its extensive assortment of ancient Assamese artefacts, utensils, jewellery and handicrafts. It also has a hundred and twenty five disciples and over 700,000 followers worldwide.

- Kamalabari Satra: The Kamalabari Satra, founded by Badulapadma Ata, is a centre of art, cultural, literature and classical studies on the Majuli island. Its branch, the Uttar Kamalabari Satra has performed cultural programmes of the Satria art in different parts of the country and abroad.

- Begenaati Satra: It is a reliquary of antiques of cultural importance and an advance centre of performing art. Muraridev, the grandson of Sankaradeva's stepmother was the founder of the Satra. The royal raiment, which belonged to the Ahom king Swargadeo Godadhar Singha, was made of gold. Also preserved is the royal umbrella made of gold.

- Shamaguri Satra: This Satra is famous for mask making in India.

These Satras are also the treasure house of 'Borgeet', Matiakhara, Satriya Nritya (Jumora Nritya, Chali Nritya, Notua Nas, Nande Vringee, Sutradhar, Ozapali, Apsara Nritya, Krishna

\footnotetext{
${ }^{1}$ Paalnaam is a compound word, pal and nam. Pal means by turn and nam means congregational prayer, chanting the name of God. Therefore, Paalnaam means holding of incessant congregational prayer or chanting of the name of God by the inmates of the Satra in-group and in rotation.
} 
Nritya and Dasavater Nritya), all promulgated by the saint Mahapurush Srimanta Sankardeva.

\section{Discussion}

With its unique geographical location, abundant natural resource base and being rooted in cultural traditions and spirituality, the Majuli river island emerged as an unique entity with nature-blessed physical and cultural attributes unmatched elsewhere in Assam. The riverine island, being cut off from elsewhere and ensconced by the river Brahmaputra, afforded a unique setting for the Satra institution to take root and develop. However, the changing geoenvironmental condition of the region especially the intensity of flooding after the 1950 earthquakes increased manifold (Lahiri and Sinha, 2012). The erosion history of Majuli can be divided into two eras: before and after the 1950 earthquake. Before 1950, erosion was insignificant, but after 1950, especially from 1954 onwards, erosion in Majuli has taken a serious turn (Sankhua et al., 2005). Due to the continued erosion of the river Brahmaputra and other tributaries, many Satras have been compelled to shift to other places. Thus, from the initial 65 Satras only 22 survives, the remaining 43 have been forced by bank erosion either to move away completely from the island or to relocate elsewhere within the island. For instance, Satras like Auniati, Uttar Kamalabari, and Dakhinpat have eroded several times. However, they have resettled within the island

\section{Acknowledgement}

The authors are highly thankful to the reviewers for their critical comments and minute observations.

\section{References}

Allen, B.C., E. A. Gait, C.G.H. Allen and H.F. Howard (1905). Gazetteers of Bengal and North-East India, Mittal Publications, Delhi, pp. 662, reprinted, 1984

Bailey, G. (2007). Time perspectives, palimpsests and the archaeology of time, Journal of Anthropological Archaeology, 26(2), pp.198223 at alternative locations: for example, the Auniati Satra changed its location six times due to erosion (Sarma, 2012). It is noteworthy to point out here that the Brahmaputra is one of the most highly flood-causing large rivers of the world, carrying an average annual flood load of $47,608 \mathrm{m3s}-1$ with a recurrence interval of 2.56 years (Bhattacharyya and Bora, 1997). Hence, recurring floods and bank erosion in the region have not only devastated the agro-based economy of the island but also the cultural heritage of the region.

\section{Conclusion}

Majuli is the pivotal centre of the Satra institution of Assam. Originally, there were more than 65 Satras in Majuli. Given its physical isolation, the pure and pristine environment, and limited exposure to outside culture, Sankardeva was prompted to select Majuli as the ideal site for establishment of the first Satra in 1522 as the place had all the requisite characteristics for such an establishment. However, over the years, due to flood and erosion hazards, the very existence of the island is at stake. In order to maintain the presence of the age-old cultural tradition of the island, the physical processes operating in the region need to be taken cognizance of and tackled if need be, to protect the island and its heritage. Necessary steps need to be taken in order to secure the future of the land, its people and the golden heritage it bears. Barua, D.K. (1994). On the environmental controls of Bangladesh river systems, Asia Pacific Journal on Environment and Development, 1(1), pp. 81-98

Bhaskar, B. P., U. Baruah, S. Vadivelu, P. Raja and D. Sarkar (2010). Remote sensing and GIS in the management of wetland resources of Majuli Island, Assam, India, Tropical Ecology, 51(1), pp. 31-40

Bhattacharyya, N.N. and A. K. Bora (1997). Floods of the Brahmaputra River in India, Water International, 22 (4), pp. 222-229, DOI: 10.1080/02508069708686709

Brammer, H. (1996). The geography of the soils of Bangladesh, University Press Ltd., Dhaka 
Caseldine, C. J., and C. Turney (2010). The bigger picture: towards integrating paleoclimate and environmental data with a history of societal change, Journal of Quaternary Science, 25(1), pp. 88-93

Coleman, J.M. (1969). Brahmaputra river: Channel process and sedimentation, Sediment Geol. 3, pp.129-239

Dwaipayan, (2013, September 25). World heritage site tag and Majuli, The Assam Tribune, (p. 6)

Fowler, P. (2004).Landscapes for the world: Conserving a global heritage. Macclesfield: Windgatherer Press

Goswami, D.C. (1985). Brahmaputra river, Assam, India: Physiography, basin denudation and channel aggradation, Water Resources Research, 21, pp.959-978

Goswami, U., J.N. Sarma, and A.D. Patgiri (1999). River channel changes of the Subansiri in Assam, India, Geomorphology, 30, pp.227244

Knight, J. and S. Harrison (2013). A land history of men: The intersection of geomorphology, culture and heritage in Cornwall, Southwest England, Applied Geography, 42, pp.186-194

Knopf, Adolph (1948). The geosynclinal theory, Geological Society of American Bulletin, 59 (7), 649-670

Kotoky, P., D. Bezbaruah, J. Baruah, and J.N. Sarma (2003). Erosion activity on Majuli - the largest river island of the world, Current Science, 84(7), pp. 929-932

Krishnan, M.S. (1982). Geology of India and Burma, CBS Publishers \& Distributors Private Ltd, New Delhi, 6th edition

Lahiri, S.K. and R. Sinha (2012). Tectonic controls on the morphodynamics of the Brahmaputra river system in the upper Assam valley, India, doi:10.1016/j.geomorph.2012.04.012

Mani, P., R. Kumar and C. Chatterjee (2003). Erosion study of a part of Majuli river-island using remote sensing data, Photonirvachak, Journal of the Indian Society of Remote Sensing, 31(1), pp. 11-18
Mcintosh, R.J. (1983). Floodplain geomorphology and human occupation of the upper inland delta of the Niger, The Geographical Journal, 149 (2), pp. 182-201

Mirza, M. M. Q., R. A. Warrick, N. J. Ericksen and G. J. Kenny (2001). Are floods getting worse in the Ganges, Brahmaputra and Meghna basins?, Environmental Hazards, 3(2), pp. 37-48, DOI: 10.3763/ehaz.2001.0305

Mirza, M.M.Q. and A. Dixit (1997). Climate change and water resources in the GBM basins. Water Nepal, 5 (1), pp.71-100

Nath, D. (2009). The Majuli island society, economy and culture, Anshah Publishing House, Delhi

North, C.P., G.C. Nanson and S.D. Fagan (2007). Recognition of the sedimentary architecture of dryland anabranching (Anastomosing), Rivers Journal of Sedimentary Research, 77, pp. 925938

Panizza, M. and S. Piacente (2008).Geomorphology and cultural heritage in coastal environments, Geografia Fisica e Dinamica Quaternaria, 31, pp. 205-210

Sankhua, R.N., N. Sharma , P. K. Garg and A. D. Pandey (2005). Use of remote sensing and ANN in assessment of erosion activities in Majuli, the world's largest river island, International Journal of Remote Sensing, 26 (20), pp. 4445-4454

Sarma, H.N. (2003). Auniatisattra: A study of its constitution to the socio-cultural and political life of Assam, an unpublished PhD Thesis, Dibrugarh University

Sarma, J.N. and M.K. Phukan (2004). Origin and some geomorphological changes of Majuli island of the Brahmaputra river in Assam, India, Geomorphology, 60, pp. 1-19

Sarma, K. (2012). Tradition and tribulation: The monastric satras of Assam, an unpublished PhD Thesis, Gauhati University

Thornbush, M. J. (2013). Introduction: Archaeogeomorphology (Geomorphology, Culture, and Place), Applied Geography, 42, pp.155-156 